\title{
Central Injection of Substance P Antagonizes the RF Amide-Related Peptide-3 Impacts on Hypothalamic KISS-1 and GnRH Gene Expressions in Male Wistar Rats
}

\author{
Parastoo Rahdar, Homayoun Khazali* \\ Department of Animal Sciences and Biotechnology, Faculty of Life Sciences and Biotechnology, Shahid Beheshti \\ University, Tehran, Iran
}

\section{*Correspondence to Homayoun Khazali, \\ Tel: +98 2129903192; Fax: +98 2122431664 Email: h_khazali@sbu.ac.ir}

Received May 21, 2018 Accepted June 18, 2018 Published online September 30, 2018

\begin{abstract}
Introduction: Gonadotropin-inhibitory hormone $(\mathrm{GnlH})$ and its mammalian orthologue RF amide-related peptide (RFRP) are known to inhibit the secretion of gonadotropins. In addition, substance P (SP), a member of tachykinin's family, can increase the firing rate of kisspeptin/ neurokinin B/dynorphin (KNDy) neurons and provoke the secretion of gonadotropins. In this experimental study, we investigated the effects of co-administration of RFRP-3 and SP on the expression of KISS-1 and GnRH genes, as gonadotropin regulator genes, in male rats.

Methods: Forty-two mature Wistar rats were randomly allocated into 7 groups $(n=6$ in each group). Animals in each group intracerebroventricularly received either saline+DMSO, SP ( $1 \mathrm{nmol})$, RFRP-3 (5 nmol), SP (1 nmol) + RFRP-3 (5 nmol), SP (1 nmol) + RF9 (RFRP-3 receptor antagonist, $10 \mathrm{nmol}), \mathrm{SP}(1 \mathrm{nmol})+\mathrm{P} 234$ (kisspeptin receptor antagonist, $1 \mathrm{nmol})+\mathrm{RFRP}-3$ (5 $\mathrm{nmol})$, or SP $(1 \mathrm{nmol})+\mathrm{CP}-96,345$ (SP receptor antagonist, $5 \mathrm{nmol})+$ RFRP-3 (5 nmol). Two hours after injections, hypothalamic samples were collected to evaluate the expression of target genes by real-time PCR.

Results: Injections in SP and SP + RF9 groups increased the expression of both $G n R H$ and KISS-1 genes $(P<0.05)$. Injections in RFRP-3 and SP + RFRP-3 + CP-96,345 groups significantly decreased the expression of GnRH and KISS-1 genes $(P<0.05)$. However, injections of SP + RFRP-3 and SP + RFRP-3 + P234 did not significantly change the expression of GnRH and KISS1 genes.

Conclusion: The results of our study indicated that SP antagonized the effects of RFRP-3 in the expression of hypothalamic KISS-1 and GnRH genes.

Keywords: RF amide-related peptid-3, Substance P, GnRH; KISS-1, Rat
\end{abstract}

Please cite this article as follows: Rahdar P, Khazali H. Central injection of substance $\mathrm{P}$ antagonizes the RF amide-related peptide-3 impacts on hypothalamic KISS-1 and GnRH gene expressions in male waster rats. Int J Basic Sci Med. 2018;3(3):127132. doi:10.15171/ ijbms.2018.23.

\begin{abstract}
Introduction
Gonadotropin releasing hormone (GnRH) plays a critical role in gametogenesis and steroidogenesis. ${ }^{1}$ Gonadotropin-inhibitory hormone $(\mathrm{GnIH})$ is one of the numerous neurohormones and neuromodulator molecules that are involved in the control of reproductive axis. GnIH, which was identified for the first time in quail, is known to inhibit the secretion of gonadotrophins by inhibiting the transcription of common $\alpha$ subunit and specific $\beta$ subunits of gonadotropins. ${ }^{2,3}$

The function of $\mathrm{GnIH}$, which is a member of RF amide family, is mediated by 2 G-protein-coupled receptors; GPR 147 and GPR 74. ${ }^{4}$ One GnIH molecule and 2 GnIH-related peptides are encoded by the
\end{abstract}

precursor mRNA of GnIH. These molecules possess LPXRF amide ( $\mathrm{X}=$ leucine or glutamine) at their $C$ terminus which is flanked by glycine and a single basic amino acid, arginine or lysine. Glycine and basic amino acids act as amidation signals and the endoproteolytic sites, respectively. ${ }^{5}$ The cDNAs identified from the brains of humans and cows encoded three GnIH orthologues, while $2 \mathrm{GnIH}$ orthologues including RF amide-related peptide- 3 and -2 (RFPR-3 and RFRP-2) were detected in rats. ${ }^{6-8}$ Dorsomedial hypothalamic (DMH) region contains GnIH neural cell bodies and the fibers of these neurons are extended to different locations including paraventricular nucleus $(\mathrm{PVN})$, preoptic area (POA), arcuate nucleus (ARC),

(C) 2018 The Author(s); Published by Zabol University of Medical Sciences. This is an open-access article distributed under the terms of the Creative Commons Attribution License (http://creativecommons.org/licenses/by/4.0), which permits unrestricted use, distribution, and reproduction in any medium, provided the original work is properly cited. 
median eminence (ME), ventral paleostriatum, optic tectum, septal area, and dorsal motor of vagus nucleus. ${ }^{9}$

In rodents, almost 33\% of GnRH neurons and 9\%-16\% of rostral periventricular kisspeptin neurons express the mRNA of the GnIH receptor. ${ }^{10}$ In hypothalamic regions of rat, there are 2 populations of kisspeptin neurons: one in the arcuate nucleus (ARC) and the other in the anteroventral periventricular nucleus (AVPV), which are involved in the negative and positive feedbacks of steroids on $\mathrm{GnRH}$, respectively. Both populations as well as $\mathrm{GnRH}$ neurons are opposed by RFRP-3 immunoreactive fibers. Therefore, GnIH can suppress the GnRH-stimulated gonadotropin secretion directly or in a kisspeptindependent manner. ${ }^{11}$ Accordingly, there are findings suggesting that the central administration of RFRP-3 reduces KISS-1 mRNA in the hypothalamus. ${ }^{12}$

There are accumulating evidence, demonstrating that tachykinins family including substance $\mathrm{P}$ (SP), neurokinin $\mathrm{A}$ and $\mathrm{B}$ exert serious impacts on the reproductive axis. ${ }^{13}$ The functions of these closely-related peptides are mediated by three G-protein-coupled receptors known as NK1R, NK2R, and NK3R. ${ }^{14}$ SP is the undecapeptide neuromodulator which is associated with nociception and inflammatory processes in the brain. SP has been reported to have a significant effect on the events leading to the preovulatory surge of luteinizing hormone $(\mathrm{LH})$ and follicle stimulating hormone (FSH) in human and mammals. ${ }^{13,15}$ The information obtained from light microscopic immunohistochemical investigations in human and rats indicated that SP neurons establish axosomatic and axodendritic inputs to GnRH neurons. ${ }^{16}$

There is strong evidence demonstrating that SP and specific NK1R agonists can promote the firing rate of kisspeptin neurons in the ARC nucleus that acts as a chief upstream pulse generator for GnRH neurons. Furthermore, the central administration of SP elevated the LH serum levels followed by an increase in the expression level of GnRH mRNA. ${ }^{17}$

Notwithstanding precise interaction of $\mathrm{GnIH}$ and SP signaling pathways as opposite inputs in modulating the expression of $G n R H$ gene and its critical upstream regulator, KISS-1 gene expression is unclear. The goal of the present investigation was to determine the impacts of central interaction of SP and RFRP-3 on the expression of GnRH and KISS-1 mRNA.

\section{Materials and Methods \\ Forty-two mature male Wistar rats (220-250 g body weight) were housed individually in cages under controlled temperature $\left(22 \pm 2^{\circ} \mathrm{C}\right)$, lighting (12-hour light/ dark cycle), and humidity (approximately 46\%), with ad libitum access to food and water all the time.}

Stereotaxic Cannulation and Intracerebroventricular Injection

The surgery on the animals was performed as previously reported. ${ }^{18}$ The animals were anesthetized using IP administration of ketamine $(80 \mathrm{mg} / \mathrm{kg} \mathrm{B.W})$ and xylazine (10 mg/kg B.W). For the central injections, a 22-gauge stainless cannula was stereotaxically implanted in the third cerebral ventricle according to the coordinates published in the Paxinos and Watson atlas $(\mathrm{AP}=-2.3$, $\mathrm{ML}=0.0, \mathrm{DV}=6.5) .{ }^{19}$ Using three stainless steel screws and dental cement, the cannula was secured to the skull in the animals kept in separate cages. To ensure that the cannula remained patent, one 27-gauge stainless steel was applied into the guide cannula. After a 7-day recovery period, animals were randomly divided into 7 groups ( $n=6$ in each group). Animals in each group intracerebroventricularly received either saline+DMSO $(3 \mu \mathrm{L}), \mathrm{SP}(1 \mathrm{nmol}), \mathrm{SP}(1 \mathrm{nmol})+\mathrm{RFRP}-3$ (5 nmol), SP $(1 \mathrm{nmol})+\mathrm{RF} 9$ (RFRP-3 receptor antagonist, $10 \mathrm{nmol})$, $\mathrm{SP}(1 \mathrm{nmol})+\mathrm{P} 234$ (kisspeptin receptor antagonist, 1 nmol) + RFRP-3 (5 nmol), or SP (1 nmol)+ CP-96,345 (SP receptor antagonist, $5 \mathrm{nmol})+\mathrm{RFRP}-3(5 \mathrm{nmol})$.

For intracerebroventricular (ICV) injections, SP (Ana Spec Co, USA), P234 (Phoenix Pharmaceutical Inc, USA), RFRP-3 (Tocris Co, USA), CP96-345 (Tocris Co, USA), and RF9 (Tocris Co, USA) were dissolved in 50\% physiologic normal saline and 50\% DMSO. Solutions in the final volume of $3 \mu \mathrm{L}$ were injected by a 27 -gauge stainless steel injector that protruded $0.5 \mathrm{~mm}$ beyond the cannula and was connected to a Hamilton micro syringe by a polyethylene tube via the third cerebral ventricle at 8:30-9:00 AM. The dosage of reagents (SP, RFRP-3, RF9, P234, CP96-345) was chosen based on previous studies which had to establish their effects in ICV injection. ${ }^{20-23}$

\section{Tissue Collection}

Two hours after the injections, all rats were anesthetized and decapitated. Brains were immediately removed and hypothalamus was obtained. The ARC nucleus (arcuate nucleus; containing kisspeptin/neurokinin B/dynorphin [KNDy] neurons) and the POA (preoptic area; containing GnRH neurons) were dissected by micro punctuation method. Tissues were stored at $-80^{\circ} \mathrm{C}$ until further assessment.

\section{Gene Expression Assay}

Total mRNAs were extracted from hypothalamic samples by using the total RNA extraction kit (Pars Tous, Iran), and were used for cDNA synthesis by Easy cDNA synthesis kit (Pars Tous, Iran). These procedures were performed according to the manufacturer's instructions. Quantitative real-time PCR with duplicate reactions were performed to evaluate mRNA levels of GnRH and KISS1 genes using gene-specific primers as shown in Table 1.

The GAPDH gene was considered as a housekeeping gene for normalizing copy number of target genes. Relative expression of GnRH and KISS-1 was determined by SYBER ${ }^{\circledR}$ Premix Ex Taq $^{\text {TM }}$ II (Takara, Japan) using Corbett-RG 6000X (Corbett Research, Australia) as 
Table.1 Primers Applied for Amplification of Selected Genes in Real Time PCR

\begin{tabular}{|c|c|c|c|}
\hline Gene & Accession Number & Sequence $\left(5^{\prime}\right.$ to $\left.3^{\prime}\right)$ & Amplicon (bp) \\
\hline \multirow[t]{2}{*}{$\mathrm{GnRH}$} & NM_012767 & F-GCCGCTGTTGTTCTGTTGACTG & 133 \\
\hline & & R-CСТССТССТTGСССАТСТСТTG & \\
\hline \multirow[t]{2}{*}{ KISS-1 } & NM_181692 & F-TGATCTCGCTGGCTTCTTGGC & 98 \\
\hline & & R-GGGTTCAGGGTTCACCACAGG & \\
\hline \multirow[t]{2}{*}{ GAPDH } & $\underline{\text { NM } 017008}$ & F-ACTTTGGCATCGTGGAAGGG & 128 \\
\hline & & R-TGCAGGGATGATGTTCTGGG & \\
\hline
\end{tabular}

follows: samples were heated for 10 minutes at $95^{\circ} \mathrm{C}$, then 40 cycles of denaturation at $95^{\circ} \mathrm{C}$ for 30 seconds, annealing at $60^{\circ} \mathrm{C}$ for 30 seconds, and extension at $72^{\circ} \mathrm{C}$ for 30 seconds. Random samples were chosen and their qualification was determined by the agarose gel electrophoresis (ethidium bromide stained 1\% agarose gel). All the amplicons represented a single peak. RTqPCR data analysis was carried out using comparative cycle-threshold (CT) method and the relative expression of target mRNAs in comparison with the reference levels was calculated by the $2^{-\Delta \Delta \mathrm{CT}}$ formula. ${ }^{24}$

\section{Statistical Analysis}

SPSS software (version 25.0) was utilized for data analysis. In order to determine the normal distribution of data, onesample Kolmogorov-Smirnov test was applied. All values were presented as mean \pm SEM. The data analysis was performed using one-way analysis of variance (ANOVA) followed by post hoc Tukey test. The significance level was considered as $P<0.05$.

\section{Results}

GnRH mRNA Expression in POA

The central infusion of RFRP-3 (5 nmol) significantly decreased the level of $G n R H$ mRNA expression compared to that of control group $(P<0.05)$. Moreover, ICV injection of SP $(1 \mathrm{nmol})$ resulted in a meaningful increase in $G n R H$ mRNA levels $(P<0.05$, Figure 1$)$.

The co-administration of SP and RFRP-3 with the mentioned dosages did not alter the expression of $G n R H$ while the co-administration of SP and RF9 led to a considerable and meaningful elevation in the expression of $G n R H$ mRNA $(P<0.05$, Figure 2).

In addition, concomitant injection of SP + RFRP-3 + P234 (1 nmol) had no significant influence on the expression of $G n R H$ mRNA compared to the control group. The expression of GnRH mRNA in POA following the injection of SP + CP-96,345 (SP receptor antagonist, $5 \mathrm{nmol}$ ) + RFRP-3 was suppressed significantly compared to that in the control group $(P<0.05$, Figure 3$)$.

KISS-1 mRNA Expression in ARC Nucleus

The central infusion of RFRP-3 (5 nmol) decreased the level of KISS-1 mRNA in ARC region in comparison with

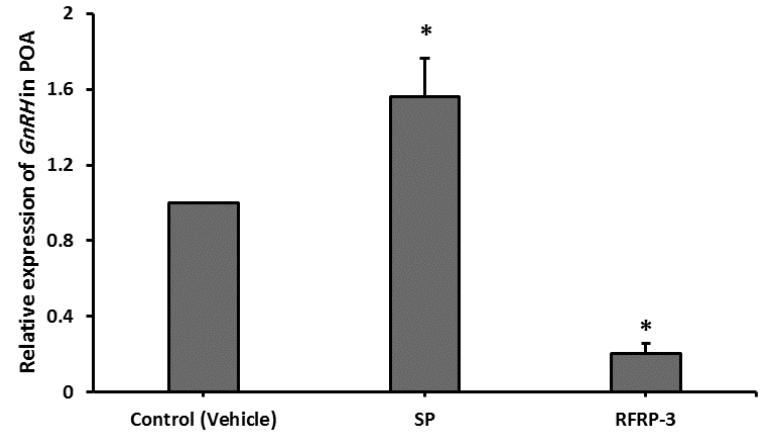

Figure 1. GnRH mRNA Expression in the Rat Preoptic Area (POA) 2 Hours After Injection of SP, and RFRP-3 Compared to the Control Group $\left(\mathrm{n}=6\right.$ per group). Data was shown as mean \pm SEM. $\quad\left({ }^{*} P<\right.$ 0.05).

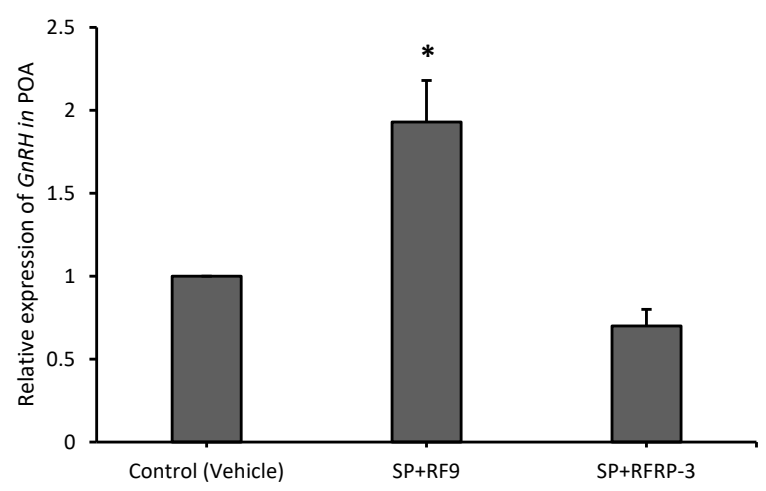

Figure 2. GnRH mRNA Expression in the Rat Preoptic Area 2 Hours After Injection of SP + RFRP-3 and SP + RF9 Compared to the Control Group ( $\mathrm{n}=6$ per group). Data was shown as mean \pm SEM $(* P<0.05)$

the control group $(P<0.05)$. Moreover, ICV injection of SP (1 nmol) resulted in a meaningful increase in KISS-1 mRNA levels $(P<0.05$, Figure 4$)$.

The co-administration of SP and RFRP-3 with the mentioned dosages did not alter the expression of KISS-1. This is while the co-administration of SP and RF9 led to a significant increase in the expression of KISS-1 mRNA in ARC $(P<0.05$, Figure 5).

The expression of KISS-1 mRNA did not significantly change following the concomitant injection of SP + RFRP-3 + P234 (1 nmol) compared to the control group. 


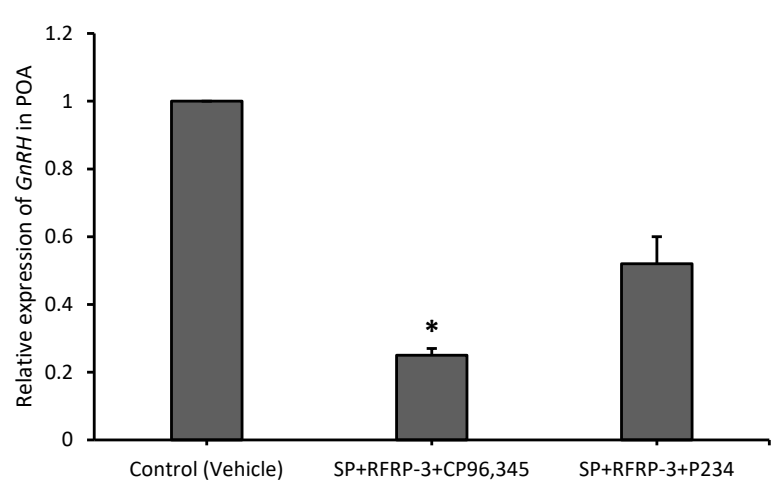

Figure 3. GnRH mRNA Expression in the Rat Preoptic Area 2 Hours After Injection of SP + RFRP-3 + P234 and SP + RFRP-3 + CP, 96345 Compared to the Control Group ( $n=6$ per group). Data was shown as mean $\pm \operatorname{SEM}\left({ }^{*} P<0.05\right)$.

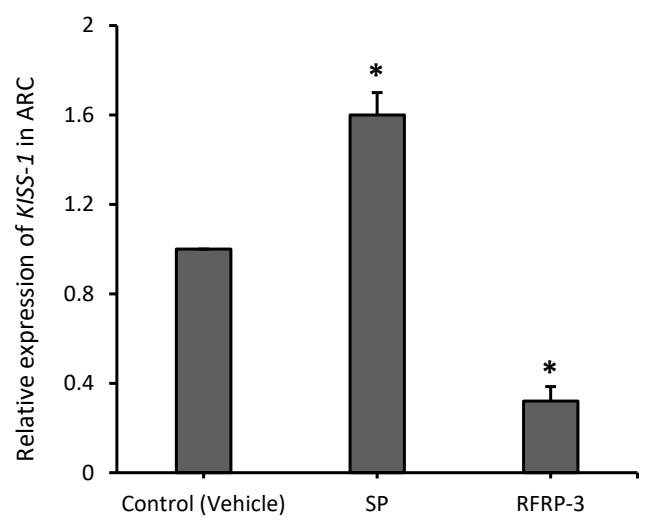

Figure 4. KISS-1 mRNA Levels in the Rat Arcuate Nucleus 2 Hours After Injection of SP, and RFRP-3 in Comparison With the Control Group ( $\mathrm{n}=6$ per group). Data was shown as mean \pm SEM $(* P<$ 0.05).

The expression of KISS-1 mRNA in the ARC nucleus was significantly inhibited following the injection of SP + CP$96,345(5 \mathrm{nmol})+\mathrm{RFRP}-3$ compared to the control group $(P<0.05$, Figure 6).

\section{Discussion}

Based on our results, the injection of RFRP-3 (5 nmol) resulted in decrement in both KISS-1 and GnRH mRNA expression levels. These data are in a good agreement with previous studies demonstrating that RFRP-3 suppressed the expression of $G n R H$ and KISS-1 genes by acting through its G-protein-coupled receptors. In addition, there are findings that demonstrate both GnRH and KISS1 expressing neurons in both ARC and AVPV nuclei also express RFRP-3 receptors (GPR 147 and GPR 74). ${ }^{25}$ In this context, other studies showed that KISS-1 expressing neural populations either in ARC or AVPV nuclei as well as GnRH expressing neurons receive inputs from RFRP-3 neurons that in rats are mainly located in DMH area. However, the proportion of the KISS-1 expressing neurons that receive these inputs varies in a species-

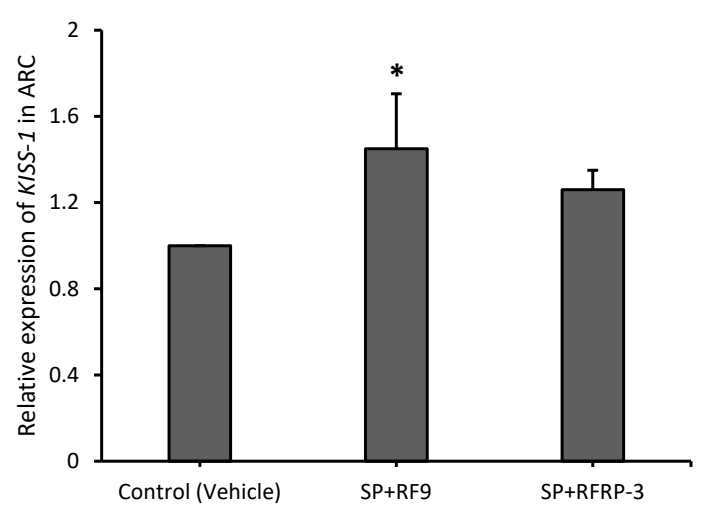

Figure 5. Relative Expression of KISS-1 mRNA in the Rat Arcuate Nucleus 2 Hours After Injection of SP + RFRP-3 and SP + RF9 Compared to the Control Group ( $\mathrm{n}=6$ in each group). Data was shown as mean \pm SEM $\left({ }^{*} P<0.05\right)$.

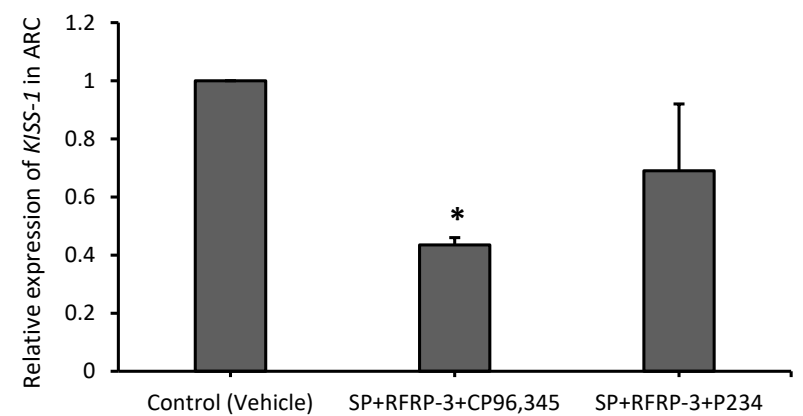

Figure 6. KISS-1 mRNA Expression in the Rat Preoptic Area 2 Hours After Injection of SP + RFRP-3 + P234 and SP + RFRP-3 + CP96,345 in Comparison With the Control Group ( $n=6$ per group). Data was shown as mean $\pm \operatorname{SEM}(* P<0.05)$.

\section{dependent manner. ${ }^{11}$}

Furthermore, our results showed that injection of SP (1 nmol) resulted in the elevation of both KISS-1 and GnRH mRNA expression; these data are in accordance with the previous findings that suggested SP, by acting through NK1R receptor, increases the activity of KNDy neurons in ARC nucleus which contains kisspeptin neurons and acts as critical upstream pulse generator of $\mathrm{GnRH}$ system. ${ }^{26}$ There are also findings, though unrevealed, that neural clusters in ARC nucleus received inputs from SPimmunoreactive fibers. ${ }^{27}$

In the present study, we demonstrated that SP antagonized the function of RFRP-3 on the expression of hypothalamic KISS-1 and GnRH genes. Furthermore, our study was the first study that determined the interaction between SP and RFRP3 as 2 opposite inputs on $\mathrm{GnRH} /$ kisspeptin system with the co-administration of them resulted in neutralizing the effects of both on the expression of KISS-1 and GnRH genes.

Besides, it was demonstrated that RF9, which is an RFRP-3 receptor antagonist and a kisspeptin agonist, had a stimulatory effect on $\mathrm{GnRH}$ system by either stimulation of KISS-1 pathway or inhibition of RFRP-3 signaling. ${ }^{28}$ 
As previous studies showed, the administration of RF9 increased the secretion of gonadotropins and promoted the effects of kisspeptin in rats. ${ }^{28}$ These functions are mediated by GPR 54 which is expressed in $\mathrm{GnRH}$ expressing neurons (agonistic effect) or by GPR147 and GPR74 which is expressed in kisspeptin and $\mathrm{GnRH}$ expressing neurons (antagonistic effect).

Furthermore, the result of our study for the first time showed that concomitant administration of SP and RF9 enhanced the effects of SP on the expression of $G n R H$ mRNA. Kisspeptin signaling pathway is considered as the main upstream regulator of $\mathrm{GnRH}$ system. There are accumulating evidence indicating that the effects of neuromodulators and neuropeptides such as SP and RFRP-3 on GnRH system are mediated by kisspeptin signaling pathway. ${ }^{29} \mathrm{P} 234$ is a potent kisspeptin receptor antagonist which was introduced in 2009. P234 inhibits the impacts of kisspeptin on HPG axis in mice, ewes, and monkeys. ${ }^{30}$ The results from previous studies indicate that the administration of $\mathrm{P} 234$ results in a considerable decrease in $\mathrm{LH}$ serum concentration level by acting through G-protein-coupled receptor 54 (GPR54) on GnRH expressing neurons. ${ }^{31}$

In the present study, we found that the co-administration of SP, RFRP-3, and P234 had no significant effect on the $G n R H$ mRNA expression. In other words, when kisspeptin signaling is blocked by P234, SP exerts its effect independent from kisspeptin signaling pathway and suppresses the function of RFRP-3. Hence other pathways may be involved in SP function on $\mathrm{GnRH}$ system. These data correspond with the studies that showed SP immunoreactive neurons projected $\mathrm{GnRH}$ neurons and provided axosomatic and axodendritic inputs to them. ${ }^{16}$ Nevertheless, the presence of NK1R on GnRH expressing neurons has not been reported. ${ }^{32}$

CP96,345 is a selective, high affinity, and non-peptide antagonist of the NK1 receptor. Studies have shown that central infusion of SP antagonist elevates the plasma levels of adrenocorticotropic hormone (ACTH) and corticosterone which are considered as stimulatory factors for the secretion of endogenous RFRP- $3 .{ }^{33}$ This evidence is in accordance with our results that demonstrated suppressive effect of SP on RFRP-3 function was eliminated by the ICV injection of SP receptor antagonist resulting in the elevation of the expression of $G n R H$ and KISS-1 genes. Nonetheless, SP receptor antagonist $(\mathrm{CP} 96,345)$ did not significantly reinforce the effects of RFRP-3 on the expression of neither GnRH nor KISS-1.

Further studies are needed to examine the interactions between other productions of KNDy neurons such as neurokinin $\mathrm{B}$ or dynorphin, which are the modulating factors involved in the activity of HPG axis.

\section{Conclusion}

In the present study, the interaction between SP and RFRP-3 on the reproductive axis in male rats was investigated for the first time. Our results indicated that SP antagonized the effects of RFRP-3 on the expression of hypothalamic KISS-1 and GnRH genes. In addition to kisspeptin signaling pathways, other pathways may be involved in the effect of SP on HPG axis.

\section{Ethical Approval}

All experiments were conducted in the Laboratory of Animal Center and in compliance with the recommendation for animal care, proposed by Animal Research Ethics Committee of Shahid Beheshti University, Tehran, Iran.

\section{Competing Interests}

The authors declare that they have no competing interests.

\section{Acknowledgment}

This study was financially supported by Shahid Beheshti University.

\section{References}

1. Bedecarrats GY. Control of the reproductive axis: Balancing act between stimulatory and inhibitory inputs. Poult Sci. 2015;94(4):810-815. doi:10.3382/ps/peu042

2. Tsutsui K, Saigoh E, Ukena K, et al. A novel avian hypothalamic peptide inhibiting gonadotropin release. Biochem Biophys Res Commun. 2000;275(2):661-667. doi:10.1006/bbrc.2000.3350

3. Bentley GE, Ubuka T, McGuire NL, et al. Gonadotrophininhibitory hormone: a multifunctional neuropeptide. J Neuroendocrinol. 2009;21(4):276-281. doi:10.1111/j.13652826.2009.01851.x

4. Bonini JA, Jones KA, Adham N, et al. Identification and characterization of two $G$ protein-coupled receptors for neuropeptide FF. J Biol Chem. 2000;275(50):39324-39331. doi:10.1074/jbc.M004385200

5. Ubuka T, Son YL, Bentley GE, Millar RP, Tsutsui K. Gonadotropin-inhibitory hormone (GnIH), GnIH receptor and cell signaling. Gen Comp Endocrinol. 2013;190:10-17. doi:10.1016/j.ygcen.2013.02.030

6. Tsutsui K, Ubuka T, Bentley GE, Kriegsfeld LJ. Gonadotropin-inhibitory hormone (GnIH): discovery, progress and prospect. Gen Comp Endocrinol. 2012;177(3):305-314. doi:10.1016/j.ygcen.2012.02.013

7. Tsutsui K. A new key neurohormone controlling reproduction, gonadotropin-inhibitory hormone $(\mathrm{GnIH})$ : Biosynthesis, mode of action and functional significance. Prog Neurobiol. 2009;88(1):76-88. doi:10.1016/j. pneurobio.2009.02.003

8. Tsutsui K, Bentley GE, Kriegsfeld LJ, Osugi T, Seong JY, Vaudry H. Discovery and evolutionary history of gonadotrophin-inhibitory hormone and kisspeptin: new key neuropeptides controlling reproduction. J Neuroendocrinol. 2010;22(7):716-727. doi:10.1111/j.13652826.2010.02018.x

9. Ubuka T, Son YL, Tobari Y, Tsutsui K. Gonadotropininhibitory hormone action in the brain and pituitary. Front Endocrinol (Lausanne). 2012;3:148. doi:10.3389/ fendo.2012.00148 
10. Rizwan MZ, Poling MC, Corr M, et al. RFamide-related peptide-3 receptor gene expression in $\mathrm{GnRH}$ and kisspeptin neurons and GnRH-dependent mechanism of action. Endocrinology. 2012;153(8):3770-3779. doi:10.1210/ en.2012-1133

11. Hu KL, Chang HM, Li R, Yu Y, Qiao J. Regulation of LH secretion by RFRP-3 - From the hypothalamus to the pituitary. Front Neuroendocrinol. 2018. doi:10.1016/j. yfrne.2018.03.005

12. Han X, He Y, Zeng G, et al. Intracerebroventricular injection of RFRP-3 delays puberty onset and stimulates growth hormone secretion in female rats. Reprod Biol Endocrinol. 2017;15(1):35. doi:10.1186/s12958-017-0254-5

13. Lasaga M, Debeljuk L. Tachykinins and the hypothalamopituitary-gonadal axis: An update. Peptides. 2011;32(9):1972-1978. doi:10.1016/j.peptides.2011.07.009

14. Kalil B, Ramaswamy S, Plant TM. The Distribution of SubstancePand Kisspeptinin the MediobasalHypothalamus of the Male Rhesus Monkey and a Comparison of Intravenous Administration of These Peptides to Release GnRH as Reflected by LH Secretion. Neuroendocrinology. 2016;103(6):711-723. doi:10.1159/000442420

15. De Felipe C, Herrero JF, O'Brien JA, et al. Altered nociception, analgesia and aggression in mice lacking the receptor for substance P. Nature. 1998;392(6674):394-397. doi: $10.1038 / 32904$

16. Dudas B, Merchenthaler I. Close juxtapositions between LHRH immunoreactive neurons and substance $\mathrm{P}$ immunoreactive axons in the human diencephalon. J Clin Endocrinol Metab. 2002;87(6):2946-2953. doi:10.1210/ jcem.87.6.8558

17. Ruiz-Pino F, Garcia-Galiano D, Manfredi-Lozano M, et al. Effects and interactions of tachykinins and dynorphin on FSH and LH secretion in developing and adult rats. Endocrinology. 2015;156(2):576-588. doi:10.1210/ en.2014-1026

18. Murakami M, Matsuzaki T, Iwasa T, et al. Hypophysiotropic role of RFamide-related peptide- 3 in the inhibition of LH secretion in female rats. J Endocrinol. 2008;199(1):105112. doi:10.1677/joe-08-0197

19. Paxinos G, Watson C. The rat brain in stereotaxic coordinates. San Diego, CA: Elsevier Academic Press; 2005.

20. Sanchez-Blazquez P, Garzon J. N-acetyl betaendorphin-(1-31) and substance $\mathrm{P}$ regulate the supraspinal antinociception mediated by $\mathrm{mu}$ opioid and alpha-2 adrenoceptors but not by delta opioid receptors in the mouse. J Pharmacol Exp Ther. 1993;265(2):835-843.

21. Ancel C, Inglis MA, Anderson GM. Central RFRP-3 Stimulates LH Secretion in Male Mice and Has Cycle StageDependent Inhibitory Effects in Females. Endocrinology. 2017;158(9):2873-2883. doi:10.1210/en.2016-1902

22. Sahin Z, Canpolat S, Ozcan M, Ozgocer T, Kelestimur H. Kisspeptin antagonist prevents RF9-induced reproductive changes in female rats. Reproduction. 2015;149(5):465473. doi:10.1530/rep-14-0683

23. Culman J, Klee S, Ohlendorf C, Unger T. Effect of tachykinin receptor inhibition in the brain on cardiovascular and behavioral responses to stress. J Pharmacol Exp Ther. 1997;280(1):238-246.

24. Livak KJ, Schmittgen TD. Analysis of relative gene expression data using real-time quantitative PCR and the 2(-Delta Delta C(T)) Method. Methods. 2001;25(4):402408. doi:10.1006/meth.2001.1262

25. Poling MC, Quennell JH, Anderson GM, Kauffman AS. Kisspeptin neurones do not directly signal to RFRP-3 neurones but RFRP-3 may directly modulate a subset of hypothalamic kisspeptin cells in mice. J Neuroendocrinol. 2013;25(10):876-886. doi:10.1111/jne.12084

26. Goodman RL, Hileman SM, Nestor CC, et al. Kisspeptin, neurokinin $\mathrm{B}$, and dynorphin act in the arcuate nucleus to control activity of the GnRH pulse generator in ewes. Endocrinology. 2013;154(11):4259-4269. doi:10.1210/ en.2013-1331

27. Kerdelhue B, Williams RF, Lenoir V, et al. Variations in plasma levels of substance $\mathrm{P}$ and effects of a specific substance $\mathrm{P}$ antagonist of the $\mathrm{NK}(1)$ receptor on preovulatory LH and FSH surges and progesterone secretion in the cycling cynomolgus monkey. Neuroendocrinology. 2000;71(4):228-236. doi:10.1159/000054540

28. Min L, Leon S, Li H, et al. RF9 Acts as a KISS1R Agonist In Vivo and In Vitro. Endocrinology. 2015;156(12):46394648. doi:10.1210/en.2015-1635

29. Seminara SB, Messager S, Chatzidaki EE, et al. The GPR54 gene as a regulator of puberty. N Engl J Med. 2003;349(17):1614-1627. doi:10.1056/NEJMoa035322

30. Roseweir AK, Kauffman AS, Smith JT, et al. Discovery of potent kisspeptin antagonists delineate physiological mechanisms of gonadotropin regulation. J Neurosci. 2009;29(12):3920-3929. doi:10.1523/ jneurosci.5740-08.2009

31. Pineda R, Garcia-Galiano D, Roseweir A, et al. Critical roles of kisspeptins in female puberty and preovulatory gonadotropin surges as revealed by a novel antagonist. Endocrinology. 2010;151(2):722-730. doi:10.1210/ en.2009-0803

32. Borsay BA, Skrapits K, Herczeg L, et al. Hypophysiotropic gonadotropin-releasing hormone projections are exposed to dense plexuses of kisspeptin, neurokinin B and substance $\mathrm{p}$ immunoreactive fibers in the human: a study on tissues from postmenopausal women. Neuroendocrinology. 2014;100(2-3):141-152. doi:10.1159/000368362

33. Jessop DS, Renshaw D, Larsen PJ, Chowdrey HS, Harbuz MS. Substance P is involved in terminating the hypothalamo- pituitary-adrenal axis response to acute stress through centrally located neurokinin-1 receptors. Stress. 2000;3(3):209-220. doi:10.3109/10253890009001125 